\title{
REPORT OF THE COMMITTEE ON TEACHING FOR THE YEAR $1920 .^{1}$
}

The Committee on Teaching for the year rgig made the following suggestions and recommendations for the consideration of the Committee on Teaching for the year 1920:

I. That a more detailed study be made of the general outline and content of the courses now being offered primarily for undergraduate credit in the various institutions.

2. That an effort be made to standardize the titles and content of the courses in agricultural economics, farm management, and allied subjects being offered in the different institutions.

3. That this inquiry be so planned as to include information regarding the regular texts, reference books, and collateral material which is being found most helpful in connection with the various courses.

In accordance with these suggestions and recommendations, your committee for the year I920 wrote to each of the forty-eight state institutions requesting the following information concerning each course offered in agricultural economic subjects: (r) Title of course; (2) credit hours for course; (3) prerequisites to course; (4) text and references used; and (5) a brief outline of the content of each course. More or less complete data were obtained from forty-six of the institutions.

From these data the committee has made the following observations:

I. The tendency to separate courses in farm management from agronomy and other departments and to include them with the courses in agricultural economics is making material progress although there are still many institutions in which farm management is included in departments of agronomy and taught as an agronomy subject.

2. The majority of the institutions in which agricultural economic work is most developed are requiring courses in general economics or agricultural economics as a prerequisite to farm management and other allied courses. These institutions have fairly uniform courses in agricultural economics and farm management. It is in the institu-

1 Report read at the eleventh annual meeting of the American Farm Economic Association, January I, I92I. 
tions that do not require some economic work as a prerequisite to farm management that the greatest variation in the content of the courses in farm management was found. These same institutions frequently included some work in the economics of agriculture, in farm organization, and in farm accounting in the same course which usually was designated as farm management.

3. Twenty-nine institutions require from three term hours to nine semester hours of either general economics or agricultural economics at some time during the college course in agriculture. The time of requiring this work varied from the beginning of the freshman year to the end of the senior year. Fifteen institutions do not require any courses in economics and the information was not available for four institutions.

4. The courses in farm accounting are based on Scovill's Farm Accounting as a text for the most part. The material available indicates that farm accounting is tending to develop along the right lines. Courses in general accounting have not made contact with the real problems of farm accounting and some courses in farm accounting have tended to sidestep rather than solve these problems.

5. The division of the field of agricultural economic instruction into the more highly specialized courses such as Marketing of Farm Products, Coöperation, Rural Credit, and Land Tenure or Land Economics has been done mostly in those institutions giving considerable attention to the economics of agriculture and there do not appear to be the tendencies to mingle the subject matter included in these courses to so great a degree as has been the case in the courses in farm management.

6. The following courses in agricultural economic subjects are offered in many institutions and may be said to be fairly well established:

A. Agricultural Economics-Taylor's Agricultural Economics is most frequently used as the text and is supplemented with Carver and Nourse.

B. Farm Management, usually given in two courses called Farm Management or Farm Organization and Advanced Farm Management, Types of Farming, or Farm Operation. Warren's is the text most frequently used with Taylor, Carver and Nourse as references and in a few cases as texts.

C. Farm Accounting-Scovill's is the text used most frequently.

D. Farm Cost Accounting-Scovill's is also used in this course.

E. Farm Surveys-offered separately by several institutions but usually combined with the courses in farm management. 
F. Marketing of Farm Products-Weld and Cherington are sometimes used as texts and when not used as texts they usually are used as references.

G. Farm Finance-also called Rural Credit and Agricultural Finance.

H. Land Tenure-also called Land Problems and Land Economics.

I. Other courses being offered by one or more institutions but not generally offered include Agricultural Statistics, Economics of Agricultural Froduction, History of Agriculture, Agricultural Geography, Agricultural Industries and in some institutions the courses in Rural Sociology are listed with the courses in Agricultural Economics.

On the basis of these observations, the committee wishes to make the following suggestions and recommendations which it believes will be particularly helpful to those institutions where the work in agricultural economics is just being introduced or has not been definitely established as yet:

I. That not less than three semester hours of general economics, or agricultural economics in which general economic principles are stressed, be required of all students in agriculture.

2. That this work in economics be required not later than the first one half of the junior year and preferably be given in a sophomore year.

3. That the course in agricultural economics be required as a prerequisite to farm management and the other specialized courses.

4. That the courses in farm accounting precede the courses in farm management whenever possible.

5. That, insofar as possible, the standard number of credit hours for all courses should be three. In general, credit hours to exceed three for a semester should be granted only to advanced students working on special problems or under special conditions.

In making these suggestions and recommendations the committee is fully aware that there may be practical difficulties which will pre-vent some of the institutions from following them, but it believes that if they are followed whenever and wherever possible, that they will result in the giving of instruction of a higher standard in all institutions, will make the transferring of credits from one institution to another easier and more fair, and make it possible to judge more accurately of the training which graduates from the various institutions have received.

Respectfully submitted,

W. E. Grimes,

Chairman. 